\title{
Activity of the ASEE Diversity Committee: Engaging a Community in Diver- sity, Advocacy, and Inclusive Practices
}

Prof. Rebecca A. Bates, Minnesota State University, Mankato

Rebecca A. Bates received the Ph.D. degree in electrical engineering from the University of Washington. She also received the M.T.S. degree from Harvard Divinity School. She is currently a Professor in the Department of Integrated Engineering program at Minnesota State University, Mankato, home of the Iron Range and Twin Cities Engineering programs.

\section{Mr. Eric Specking, University of Arkansas}

Eric Specking serves as the Director of Undergraduate Recruitment for the College of Engineering at the University of Arkansas. He directs the engineering recruitment office, most of the College of Engineering's K-12 outreach programs, and the college's summer programs. Specking is actively involved in the Industrial Engineering and Engineering Management divisions and is the current Chair of the ASEE Diversity Committee. Specking received a B.S. in Computer Engineering and a M.S. in Industrial Engineering from the University of Arkansas and is currently working on a PhD in Industrial Engineering at the University of Arkansas.

\section{Dr. Adrienne Minerick, Michigan Technological University}

Adrienne Minerick is the Associate Dean for Research \& Innovation in the College of Engineering and Assistant to the Provost for Faculty Development at Michigan Tech. She received her M.S. and Ph.D. from the University of Notre Dame and B.S. from Michigan Tech. Adrienne's research interests include electrokinetics, predominantly dielectrophoretic characterizations of cells, and the development of biomedical microdevices. She earned a NSF CAREER award and was nominated for Michigan Professor of the Year in 2014. Research within her Medical micro-Device Engineering Research Laboratory (M.D. - ERL) also inspires the development of Desktop Experiment Modules (DEMos) for use in chemical engineering classrooms or as outreach activities in area schools (see www.mderl.org). Adrienne is past Chair of ASEE's Diversity Committee and past PIC I Chair; she has previously served on WIED, ChED, and NEE leadership teams and has contributed to over 40 ASEE conference proceedings articles.

\section{Dr. Stephanie Farrell, Rowan University}

Dr. Stephanie Farrell is Professor and Founding Chair of Experiential Engineering Education at Rowan University (USA), Immediate Past Chair of the ASEE Diversity Committee, and will serve ASEE as President in 2017-2018. From 1998-2016, Stephanie was a faculty member in Chemical Engineering at Rowan. Dr. Farrell has contributed to engineering education through her work in experiential learning, focusing on areas of pharmaceutical, biomedical and food engineering. She has been honored by the American Society of Engineering Education with several teaching awards such as the 2004 National Outstanding Teaching Medal and the 2005 Quinn Award for experiential learning. She was also a Fulbright Scholar in Engineering Education at Dublin Institute of Technology (Ireland).

\section{Dr. Rocio C. Chavela Guerra, American Society for Engineering Education}

Rocio Chavela is Director of Education and Career Development at the American Society for Engineering Education (ASEE). She holds a Ph.D. in Engineering Education from Purdue University, a B.S. and a M.S. in Chemical Engineering from Universidad de las Americas, Puebla in Mexico. Rocio's current efforts focus on engineering faculty and graduate student development, with particular emphasis on the adoption of evidence-based instructional practices. 


\section{Activity of the ASEE Diversity Committee: Engaging a Community in Diversity, Advocacy, and Inclusive Practices}

The Diversity Committee of the American Society for Engineering Education (ASEE) has been engaged in advocacy since 2010 . This paper will provide descriptions of the committee history, practices, and activities that have brought increased visibility of the need for an inclusive engineering field and professional society as well as strategies to accomplish inclusivity. As a professional society, ASEE is addressing the inequities in the field of engineering education through many activities. The Diversity Committee has built on the foundational work of multiple divisions within the society such as the Minorities in Engineering and Women in Engineering divisions. As an umbrella entity with representation from many divisions, the Diversity Committee's activities have grown, expanding from co-sponsoring conference programming and offering Safe Zone workshops, to a formal paper program with special sessions. Challenges within ASEE have included bridging conversations and perspectives between technical-focused divisions and thematic divisions, as well as crafting responses to societal challenges that affect engineering students, faculty, and practitioners.

Representatives of the ASEE Diversity Committee are recording this for posterity and to encourage engagement within other academic institutions and professional societies. Some of our examples and strategies can be scaled and adapted to address institutional or regional challenges or to increase awareness and engagement in other national societies. Outcomes seen through initiatives have resulted in increased connections with previously disenfranchised members to the ASEE community, engagement across divisions, and expanded programming in support of diversity, equity, and inclusion practices.

\section{Importance of Diversity, Equity, and Inclusion}

Engineers have a significant impact on society. Their actions shape future technology, infrastructure, and innovation. Improving workforce diversity has been shown to improve innovation, productivity, and financial performance [1]-[3], but the engineering workforce is lacking in diverse representation. For example, 57\% of the 2016 engineering bachelor's degrees were awarded to Caucasian students and $79 \%$ were awarded to male students [4]. This need for diversity in STEM has been recognized by the National Academies as a priority [5].

Increasing diversity is typically used to refer to increasing the representation of underrepresented minority groups, such as women or racial/ethnic minorities, but Haring-Smith demonstrate the need to expand diversity to include other dimensions such as socioeconomic status, religious belief, veteran status, ability, age, and sexual orientation [6]. This expansion contributes to creating a more inclusive environment, which is an environment that allows all individuals the opportunity to achieve their full potential [7]. Inclusive environments value the uniqueness and social differences of its participants. In fact, Bendick demonstrated that a lack of diversity creates a less inclusive organization [8]. A "chilly climate" is often cited as a major factor for a student leaving STEM, especially members of underrepresented groups [9]. This "chilly" climate is caused by a lack of inclusion. Therefore, the climate must be created to embrace inclusion and allow individuals to fully participate and contribute. 
Creating an inclusive environment is difficult. Too many populations have been marginalized over the years, which creates exclusion, discrimination, bias, hostility, and severe barriers to participation. Marginalization also manifests into unique challenges for each marginalized population. This demonstrates the need for equity practices, which focus on concern for people's differential needs. These needs can be related to individual differences related to identity, or those created by historical inequities and circumstances. The subtle difference between equality and equity is important. Equality assumes everyone has the same needs and that everyone starts at the same point, while equity provides all participants what they need to be successful. This is why when diversity is being discussed, there is a need to include both equity and inclusion.

\section{Vision, Mission \& Strategic Action Plan}

The activities of the ASEE Diveristy Committee have been guided by a communal vision and have informed and been informed by (a) the task force charge in 2009, (b) initial plans developed by the committee in 2011-12, (c) and a formal strategic action plan developed in 2015-16. The ASEE statement on diversity and inclusion describes the Society's vision as

to create and foster environments where every individual is respected and no one feels marginalized. ASEE believes that this can be achieved by supporting the education, recruitment, retention, and advancement of these groups in engineering education, engineering technology education, and the engineering profession. While ASEE recognizes that steady gains have been made in the number of women, AfricanAmericans, Hispanics, and Native Americans in engineering over the past several years, substantial progress must still be made to reach a state where engineering is fully empowered by all segments of our society, and particularly those who have been historically under-represented.[10]

This was the foundation for the ASEE Diversity Committee's vision, which is one of "widespread, inclusive, and equitable environments in engineering, academia, and industry that embrace individual differences and leverage diversity for a better engineered tomorrow" [11].

This vision, in conjunction with the ASEE statement on diversity and inclusion, provides the long term direction to work towards. The ASEE Diversity Committee made its mission to increase visibility and discussion of diversity, equity, and inclusion issues, report findings and activities to the ASEE Board of Directors, develop guidance to foster inclusive environments in which all engineers thrive, and facilitate and encourage the adaptation of strategies to promote the empowerment of all.

The ASEE Diversity Committee plans to accomplish its mission and reach the vision through two major goals that each use three strategies. The first goal is internally focused on ASEE as an organization and is to "increase visibility, improve baseline knowledge, empower members, and leverage events within ASEE and ASEE affiliates to increase diversity" [12]. This goal contains three strategies: 1) engage the ASEE community to improve baseline knowledge of diversity issues, 2) empower ASEE members into actionable initiatives, and 3) partner with Engineering Deans Council (EDC), Engineering Technology Council (ETC), Corporate Member Council (CMC), Engineering Research Council (ERC), divisions, sections, zones, and other groups [12]. 
The second goal focuses on the overall engineering environment and is to "increase visibility of and perceived importance of diversity within all engineering and related communities" [12]. This goal's strategies are to 1) be a proactive voice to influence policies and practices on a national and global scale, 2) develop partnerships that recognize and disseminate information and strategies to a larger audience, and 3 ) engage the broader engineering community (academia, industry, government) to actively and steadily increase diversity [12].

\section{History \& Activities}

In 2002, an ASEE task force was charged with creating a diversity statement with associated strategies and measureable outcomes. This produced a document with several strategies, but none of the proposed strategies were implemented. In 2009, based on initial conversations in 2008, then ASEE President Sarah Rajala created a formal Diversity Task Force to (a) create a mission, vision, and diversity statement; (b) heighten visibility of diversity in the organization; (c) develop a statement on commitment to diversity and focus on how ASEE can increase numbers of women and minorities pursuing degrees in engineering; and (d) come up with an action oriented, 3-5 year strategic plan to support the mission that includes benchmarks and evaluation.

The Diversity Task Force was formalized as an ASEE Board of Directors committee in 2011 as an opportunity for action driven by committed leaders and members. This committee built upon the effort of the previous Diversity Task Force and developed a new strategic diversity plan when it formed in 2012-2013. Committee members included representatives from the Minorities in Engineering Division, the Women in Engineering Division, the K-12 Division, the Engineering Dean's Council, the Corporate Member Council, the Engineering Technology Council, and engineering diversity organizations, three members-at-large, and a headquarters staff representative.

The ASEE Board of Directors continued its commitment to diversity by authorizing 2014-2015 as the Year of ACTION on Diversity where members were called to discuss, engage, and highlight activities that help advance the Society's diversity efforts and inclusivity [13]. This call provided a means to start a majority approach by getting everyone involved in diversity efforts [13]. The original strategic plan was modified in 2015-2016 to determine which initiatives were internally or externally focused and to connect activities and data to each goal, as described in Section 2 and available online [12].

The actions of the committee have grown organically to address the needs, initiatives, and concerns of the Society's members, Diversity Committee members, and Diversity committee delegates. The Committee has increased activities from raising awareness to dialog to scholarly action by pulling in multiple marginalized groups, researchers, practitioners, and advocates for discussion and participation. It is evident that change is occurring, change that moves beyond just talking about issues to a greater involvement among Society members and groups, inclusion practices, and normalization of these practices.

Each successive leader of the Diversity Committee has shepherded progress towards meeting the Diversity Committee's vision. Activities have grown and expanded as committee capacity, 
Table 1. Diversity Committee Leadership and Conference Location

\begin{tabular}{|c|c|c|}
\hline Years & Leader & ASEE Conference Location \\
\hline $2011-2013$ & Bevlee Watford & $\begin{array}{c}\text { Vancouver 2011 } \\
\text { San Antonio 2012 } \\
\text { Atlanta 2013 }\end{array}$ \\
\hline $2013-2014$ & Teri Reed \& Adrienne Minerick & Indianapolis 2014 \\
\hline $2014-2015$ & Teri Reed & Seattle 2015 \\
\hline $2015-2016$ & Adrienne Minerick & New Orleans 2016 \\
\hline $2016-2017$ & Stephanie Farrell & Columbus 2017 \\
\hline $2017-2018$ & Eric Specking & Salt Lake City 2018 \\
\hline $2018-2019$ & Rebecca Bates & Tampa 2019 \\
\hline
\end{tabular}

experience, and passion have come into play. Table 1 shows the progression of leadership, including a transition from a Chair structure to a Co-Chair structure to a Vice-Chair, Chair, and Past-Chair structure, to adapt to increased responsibilities and aid with continuity. Highlights of activities are provided in sections 3.1 to 3.8 .

\subsection{9-2011: Task Force Years}

Sarah Rajala emphasized diversity during her term as president from 2008-2009. She created the Diversity task force asking Bevlee Watford to lead the effort. The task force:

- divided work by target group (pre-college, undergraduate student, graduate student, and faculty);

- worked in pairs to create lists of desired actions related to each target group; and

- coordinated via monthly teleconferences and simultaneously created the strategic plan from the lists of actions.

The process took six months and was compiled into a report delivered to ASEE President Rajala. The next priority was to enable the formation of a standing committee of the board. There were challenges in making a strong case for a new committee, but ultimately it was supported by the ASEE Board of Directors. By 2011, the committee was formed with Watford as chair.

\subsection{1-2013: Committee Inception (Chair: Bevlee Watford)}

During this period, processes, interactions, and timelines were formalized and institutionalized into ASEE annual procedures. Committee activities included:

- regular teleconferences;

- programming with the Engineering Deans Council (EDC);

- regular dialogue with the Board of Directors; and

- diversity booth at Annual Conference \& Exhibition (sponsored by industry). 
This time period included some struggles to get critical momentum going, although perseverance prevailed until the committee reached a critical mass of members. Much of this progress was the impact of Bevlee Watford's role as a charismatic and direct-speaking leader. Processes became more institutionalized, which helped set ASEE precedents to move from good ideas, to action and implementation, to institutionalization and sustainability. A reflection on this period is provided in the Spring 2014 Diversity Committee newsletter by J.P. Mohsen, ASEE former President [14].

\subsection{3-2014 (Chairs: Teri Reed \& Adrienne Minerick)}

Teri Reed and Adrienne Minerick agreed to co-chair the Diversity Committee following Watford's leadership. Reed and Minerick collaborated to help ASEE prepare for the Year of ACTION on Diversity for the following year. During 2013-2014, they accomplished work such as:

- performing necessary background work to get the Year of ACTION on Diversity approved;

- defined Year of ACTION on Diversity scope and impact areas;

- initiated and institutionalized the Year of ACTION website (http://diversity.asee.org) and the Diversity Committee twitter feed;

- worked with the ASEE Board of Directors to get a more expansive diversity statement approved [10];

- interacted with division executive boards to promote addition of diversity statements to division bylaws;

- developed and circulated newsletters on Diversity Committee efforts;

- worked with the ASEE Board of Directors to get approval for and to institutionalize the ASEE Best Diversity Paper;

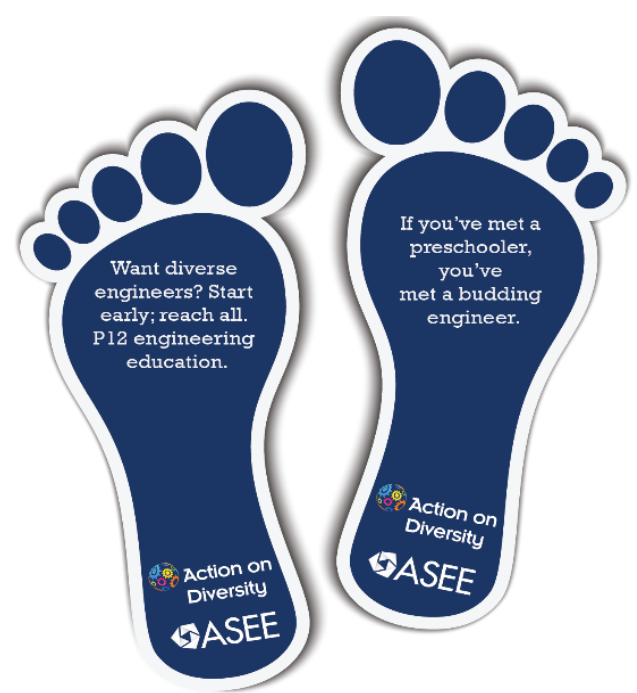

Figure 1. Example of Footsteps from 2017 Annual Conference

- piloted the footsteps project, where large stickers were placed on the floor throughout the convention center in Indianapolis in high traffic spaces (see Figure 3);

- created the call for papers and an assessment tool for the ASEE Best Diversity Paper; and

- worked with ASEE information technology staff to identify potential papers within the paper review system.

\subsection{4-2015 (Chair: Teri Reed)}

The work by Reed and Minerick laid the ground for the 2014-2015 Year of ACTION on Diversity. This also was the first year for the more sustainable chair rotation leadership structure. Reed became chair of the Diversity Committee with Minerick serving in the Chair-elect role. During this time, the committee had strong engagement from the Engineering Deans Council and Corporate Member Council, but the committee struggled with building impact and funding. The Diversity Committee:

- facilitated the publication of diversity-focused articles in Prism;

- developed partnerships with over 15 organizations including diversity organizations like WEPAN and technical societies like AIChE; 
- partnered with ASEE to offer a Micromessaging webinar by Stephen Young at a discounted rate for ASEE members;

- participated in the exhibitor part of the ASEE Annual conference by having a Diversity Booth at the entrance of the Exhibit Hall so that diversity in engineering was prominent to attendees and exhibitors. The booth was populated with committee members for 2.5 days, with raffles of donated prizes to draw in visitors for conversations and information from each partner organization and sponsors like NOGLSTP;

- $\quad$ provided rainbow ribbons for attendees to decorate name badges to promote LGBTQ+ inclusiveness;

- $\quad$ solidified the Footsteps initiative with diversity-focused messages; and

- sponsored or co-sponsored a variety of panels (Interactive Panel on Improving the Experiences of Marginalized Students on Engineering Design Teams and Interactive Panel on Perspectives and Practical Skills for Men as Advocates for Gender Equity), paper sessions, and trainings at the Annual Conference (summarized in Figure 4). These attracted diverse panelists and moderators for multiple diversity-focused sessions (e.g., Best Diversity Papers; Diversity in Chemical Engineering Education: Status and Perspectives).

\begin{tabular}{|c|c|c|}
\hline Monday, June 15 & Tuesday, June 16 & Wednesday, June 17 \\
\hline \multirow[t]{2}{*}{$\begin{array}{l}\text { 7:00 am to 8:30 am } \\
\text { Safe Zone/Positive Space Ally Training } 1 \\
\text { (Level 1) }\end{array}$} & $\begin{array}{l}\text { 7:00 am to } 8: 30 \text { am } \\
\text { Safe Zone/Positive Space Ally Training } 2 \\
\text { (Level 1) }\end{array}$ & $\begin{array}{l}\text { 7:00 am to 8:30 am } \\
\text { Safe Zone/Positive Space Ally Training } 6 \\
\text { (Level 1) }\end{array}$ \\
\hline & $\begin{array}{l}\qquad 8: 45 \text { am - 10:15 am } \\
\text { Round Table Discussions on Diversity \& } \\
\text { Inclusivity } \\
\text { (Engineering Libraries Division, Engineering } \\
\text { Physics and Physics Division, Engineering } \\
\text { Ethics Division) }\end{array}$ & $\begin{array}{l}\quad 8: 45 \text { am to } 10: 15 \text { am } \\
\text { Turning Points Panel: Addressing Diversity- } \\
\text { Related Challenges } \\
\text { (Engineering Libraries Division, Engineering } \\
\text { Physics and Physics Division ) }\end{array}$ \\
\hline $\begin{array}{l}12: 30 \mathrm{pm} \text { to } 2: 00 \mathrm{pm} \\
\text { Best Diversity Papers Session } \\
\text { (Engineering Libraries Division, } \\
\text { Educational Research Methods Division) }\end{array}$ & & $\begin{array}{l}12: 30 \mathrm{pm} \text { to } 2: 00 \mathrm{pm} \\
\text { Safe Zone/Positive Space Ally Training } 7 \\
\text { (Level 2) } \\
\text { (Student Division) }\end{array}$ \\
\hline \multirow[t]{3}{*}{$\begin{array}{c}2: 15 \mathrm{pm} \text { to } 3: 45 \mathrm{pm} \\
\text { Cognitive Diversity: Peering into the Black } \\
\text { Box } \\
\text { (Engineering Libraries Division, } \\
\text { Educational Research Methods Division) }\end{array}$} & $\begin{array}{c}2: 15 \mathrm{pm} \text { to } 3: 45 \mathrm{pm} \\
\text { Safe Zone/Positive Space Ally Training } 3 \\
\text { (Level 1) }\end{array}$ & $\begin{array}{l}\text { 2:15 pm to } 3: 45 \mathrm{pm} \\
\text { Panel: The Microaggressions Experienced by } \\
\text { Non-traditional Marginalized Groups in } \\
\text { Engineering } \\
\text { (Engineering Libraries Division) }\end{array}$ \\
\hline & $\begin{array}{l}\text { 4:00 pm to } 5: 30 \mathrm{pm} \\
\text { Safe Zone/Positive Space Ally Training } 4 \\
\text { (Level 2) }\end{array}$ & $\begin{array}{l}\text { 4:00 pm to } 5: 30 \mathrm{pm} \\
\text { Safe Zone/Positive Space Ally Training } 8 \\
\text { (Level 1) } \\
\text { (Chemical Engineering Division, Student } \\
\text { Division) }\end{array}$ \\
\hline & $\begin{array}{c}5: 45 \mathrm{pm} \text { to } 7: 15 \mathrm{pm} \\
\text { Safe Zone/Positive Space Ally Training } 5 \\
\text { (Level 1) } \\
\text { (Engineering Ethics Divison) }\end{array}$ & \\
\hline
\end{tabular}

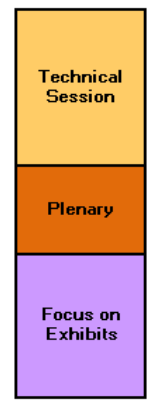

Figure 2. 2014-2015 Annual Conference Schedule for Diversity Committee Programming

\subsection{5-2016 (Chair: Adrienne Minerick)}

Because of the challenges of working within an organizational structure, including how members are nominated, work from 2015-2017 included planning and procedure development. Minerick continued her work from previous years and helped lead the Diversity Committee to: 
- revised the strategic plan which included measures and metric goals [12];

- began a Diversity Committee Delegates program where any division that included a diversity and/or inclusion statement in their bylaws was able to appoint a delegate to the committee;

- continued the Year of ACTION activities including footsteps and Diversity Booth;

- expanded and refined the Best Diversity Paper Competition;

- increased visibility amongst the ASEE community through regular newsletters and an enhanced conference programming (see Figure 5);

- started the \#ASEEIncludes initiative with Diversity Committee T-shirts for sale at the Annual Conference and associated social media posts highlighting booth activity;

- created the student Diversity Essay and Video Competitions; and

- strongly encouraged ABET to include diversity and inclusion concepts as they considered changes to accreditation outcomes.

The Diversity Committee was awarded WEPAN's 2016 Strategic Partner Award for its efforts on the Year of ACTION on Diversity under Minerick's and Reed's leadership.

\begin{tabular}{|c|c|c|c|}
\hline & Monday, June 27 & Tuesday, June 28 & Wednesday, June 29 \\
\hline $8: 00$ & Plenary & \multirow[t]{2}{*}{$\begin{array}{l}\text { Safe Zone Ally Training } \\
\text { (Level 1) }\end{array}$} & \multirow[t]{2}{*}{$\begin{array}{l}\text { Safe Zone Ally Training } \\
\text { (Level 1) }\end{array}$} \\
\hline 9:00 & & & \\
\hline 10:00 & $\begin{array}{l}\text { Focus on Exhibit } \\
\text { NSF Poster Session }\end{array}$ & Plenary & Turning Points Panel \\
\hline 11:00 & \multirow[b]{2}{*}{$\begin{array}{l}\text { Safe Zone Ally Training } \\
\text { (Level 1) }\end{array}$} & \multirow[b]{2}{*}{ Focus on Exhibit } & \multirow[b]{2}{*}{$\begin{array}{l}\text { Safe Zone Ally Training } \\
\text { (Level 1) }\end{array}$} \\
\hline $12: 00$ & & & \\
\hline 13:00 & \multirow{2}{*}{ Best Diversity Papers Session } & \multirow{2}{*}{$\begin{array}{l}\text { Men Allies for Gender Equity } \\
\text { (Male participants only) }\end{array}$} & \multirow{2}{*}{ Students with Disabilities } \\
\hline 14:00 & & & \\
\hline 15:00 & $\begin{array}{l}\text { Safe Zone Ally Training } \\
\text { (Level 2) }\end{array}$ & $\begin{array}{l}\text { Men Allies for Gender Equity } \\
\text { (Open to all) }\end{array}$ & $\begin{array}{l}\text { Safe Zone Ally Training } \\
\text { (Level 2) }\end{array}$ \\
\hline & \multirow[t]{2}{*}{ Focus on Exhibit } & \multirow{2}{*}{$\begin{array}{l}\text { Roundtable Discussions on } \\
\text { Diversity \& Inclusivity }\end{array}$} & \\
\hline 17:00 & & & \\
\hline 18:00 & Awards Ceremony & \multirow{3}{*}{ Division Social Events } & \multirow{3}{*}{ President's Farewell Reception } \\
\hline 19:00 & \multirow{2}{*}{ Division Social Events } & & \\
\hline 20:00 & & & \\
\hline
\end{tabular}

Figure 3. 2015-2016 Annual Conference Schedule for Diversity Committee Programming 


\subsection{6-2017 (Chair: Stephanie Farrell)}

Farrell served under Minerick as chair-elect and continued Minerick's direction as chair. Farrell led the Diversity Committee to:

- significantly change the conference program by adding a formal paper program, shown in Figure 6 and further discussed in Section 4;

- created a more interactive Diversity Booth space by turning the booth into a Pavilion with a photo booth and comment wall, and an expanded area to congregate for conversations about diversity, equity and inclusion;

- continued the \#ASEEIncludes branding on the diversity T-shirt initiative;

- collaborated with the PK-12 Committee to support programming related to the Year of Action on PK-12;

- worked with ASEE headquarters to develop and present Safe Zone workshops as online webinars (supported in part by National Science Foundation grants EEC-1539140 and EEC1748499); and

- continued to encourage divisions to include diversity statements in their division bylaws.

\begin{tabular}{|c|c|c|c|}
\hline Sunday, June 25 & Monday, June 26 & Tuesday, June 27 & Wednesday, June 28 \\
\hline $\begin{array}{l}\text { Papers: Engineering } \\
\text { Workforce \& Faculty } \\
\text { Training 8-9:30 }\end{array}$ & & $\begin{array}{l}\text { Papers: Supporting } \\
\text { Students at Multiple } \\
\text { Levels 8-9:30 }\end{array}$ & $\begin{array}{l}\text { Safe Zone Ally Training } \\
\text { (Level 1) 8-9:30 }\end{array}$ \\
\hline $\begin{array}{l}\text { Papers: Institutional } \\
\text { Change \& Perspectives on } \\
\text { Diversity 9:45-11:15 }\end{array}$ & & & \\
\hline $\begin{array}{l}\text { Safe Zone Ally Training } \\
\text { (Level 1) 11:30-1 }\end{array}$ & $\begin{array}{c}\text { Workshop: Diversity } \\
\text { Student Support } \\
\text { Programs 11:30-1 }\end{array}$ & & $\begin{array}{c}\text { Roundtable Discussions } \\
\text { on } \\
\text { Diversity \& Inclusivity } \\
11: 30-1\end{array}$ \\
\hline \multirow{2}{*}{$\begin{array}{l}\text { Allies for Gender Equity } \\
\text { (2 sessions: Men only \& } \\
\text { all welcome) 2:30-3:45 }\end{array}$} & $\begin{array}{l}\text { Best Diversity Papers } \\
\text { Session 1:30-3 }\end{array}$ & $\begin{array}{c}\text { Papers: Disability } \\
\text { Experiences \& Empathy } \\
1: 30-3\end{array}$ & $\begin{array}{c}\text { Safe Zone Deep Dive: } \\
\text { Supporting Transgender } \\
\text { Students and Colleagues } \\
1: 30-3\end{array}$ \\
\hline & $\begin{array}{l}\text { Safe Zone Ally Training } \\
\text { (Level 2) 3:15-4:45 }\end{array}$ & $\begin{array}{l}\text { Allies for Gender Equity } \\
\text { (2 sessions: Men only \& } \\
\text { all welcome) } 3: 15-4: 45\end{array}$ & $\begin{array}{l}\text { Safe Zone Ally Training } \\
\text { (Level 2) 3:15-4:45 }\end{array}$ \\
\hline
\end{tabular}

Figure 4. 2015-2016 Annual Conference Schedule for Diversity Committee Programming

Other activitiy this year included the Engineering Dean's diversity initiative which was inspired by committee activity and led by Engineering Deans Council Representative to the Diversity Committee, Yannis Yortsos [15]. 


\subsection{7-2019 (Eric Specking, 2017 Chair, and Rebecca Bates, 2018 Chair)}

Specking learned the importance of advocacy, equity, and inclusion from Minerick and Farrell. He wanted to increase the sustainability of the Diversity Committee through a formalized structure and better branding. Specking and Bates, along with the rest of the Diversity Committee leadership team (sub-committee chairs), collaborated from the beginning to ensure that all initiatives would continue throughout both of their terms. Their 2 year goals have been to:

- highlight more dimensions of diversity (inclusion and equity) by proposing a new committee name (Committee on Diversity, Equity, and Inclusion) to better reflect the values of the diversity statement;

- maintain all current initiatives (paper program, conference pavilion or booth, ASEE Best Diversity Paper, Student Essay/Video Competition, etc.);

- develop operational procedures to ensure a more sustainable organization structure;

- align sub-committee activities and new initiatives with the ASEE Diversity Committee Strategic Plan;

- create a formal reporting mechanism for Strategic Plan reporting;

- align the ASEE Diversity Committee Strategic Plan with the ASEE's mission, vision, and strategic doing;

- regularly update the Diversity Committee website to be more sustainable and useful to stakeholders;

- increase the number of diversity paper submissions;

- increase committee member participation;

- increase the number of ASEE Division delegates by removing the division bylaw requirement;

- build and expand partnerships with other professional societies; and

- better brand \#ASEEIncludes the Diversity Committee through a cohesive logo and branding in committee produced material.

\subsection{Conference Programming}

Much of the visible action of the committee to support action on inclusion has been in conference programming. This has grown from an industry-sponsored booth, to activities such as Safe Zone training during every technical session slot, to a Best Paper competition, to a call for papers and paper sessions at the conference. A summary of the progression under the leaders described above has been:

1) Louisville 2010: Coalition building and setting the foundation.

2) Vancouver 2011: Diversity bookmark and flyer prepared for attendees.

3) San Antonio 2012: A diversity area in the conference exhibit hall to promote awareness as well as provide a conversation space was staffed, with activities sponsored by Dupont.

4) Atlanta 2013: A microaggressions workshop held for a specific audience at the Engneering Deans Council meeting was translated to an ASEE conference workshop for 35-40 people, run by Bevlee Watford.

5) Indianapolis 2014: Along with a diversity booth near the front of the exhibition space, "footprints" were first added to the floor of the conference center. In response to the Helmer Letter [16], [17], Safe Zone workshops [18] were added during 12 session time slots, advocated by Adrienne Minerick in her role as PIC chair. These were organized by 
Stephanie Farrell. Funding for the diversity booth and committee activities was provided through support from Viterbi, Michigan Tech, and Rowan University.

6) Seattle 2015: Along with the diversity booth, footprints and Safe Zone workshops, programming included a Round Table on Diversity session, an opportunity for attendees to participate in community conversations about topics related to diversity and incusion, and a student panel, highlighting the diverse experiences of engineering students. This year was the Year of ACTION on Diversity and the diversity booth had six corporate and institutional sponsors. To celebrate the Year of ACTION, the ASEE Best Diversity Paper Award was initiated [19], and the committee sponsored a session highlighting the best diversity-related papers selected from those nominated by ASEE divisions.

7) New Orleans 2016: Along with maintaining the diversity booth activity, footprints, Safe Zone workshops, Best Paper award, and Round Table discussion session, the hashtag \#ASEEIncludes was introduced with T-shirts where attendees could write what aspect of their experience was included in ASEE and an Ally workshop based on findings from the North Dakota State University ADVANCE project [20] were added. This year, ASEE was the full sponsor for the diversity booth, indicating the strong commitment of the society to diversity and inclusion.

8) Columbus 2017: A significant addition to Committee programming was a call for papers and special sessions, developed in 2016, that resulted in a conference program that included Safe Zone workshops and Ally workshops as in previous programs, but also workshops for facuty and advisors, peer-reviewed papers responding to the call, and a session of best diversity papers from across the conference. Again, ASEE was the full sponsor for the booth.

\section{Highlighting Scholarly Activity}

In 2017, the Diversity Committee introduced traditional publish-to-present paper sessions at the ASEE Annual Conference. This was in part a response to the papers nominated for the Best Diversity Paper award. The Diversity Committee maintains a position of supporting a broad definition of diversity and recognized a need to provide a space for papers on diversity-related topics that were not the historical focus of other divisions within the organization. That year, twenty-two papers were accepted for presentation at the annual conference; this was above and beyond the papers submitted to the Minorities in Engineering Division (MIND), the Women in Engineering Division (WIED) and other divisions that include diversity topics such as Education Research \& Methods and Liberal Education/Engineering \& Society. The Diversity Committee's four paper sessions highlighted aspects of inclusion and best practices as well as promoting diversity in many aspects of engineering and engineering education. A few of the topics represented among the papers were latent diversity, supporting students with disabilities, and the inequality of LGBTQ students in engineering. This paper track was essential to help provide an archival record of the engineering education diversity, inclusion, and equity related scholarship. Before this, the ASEE conference lost diversity related work due to the lack of an alignment between the calls for papers and the broad range of scholarship related to diversity, inclusion, and equity. The 2018 call for papers resulted in 40 abstracts and 19 papers accepted in the Diversity track. 


\section{Consensus-based Decision Making}

A key technique that the Diversity Committee uses is consensus-based decision making (for more information see [21] and [22]). This supports our goal of engaging others by building community buy in for committee activities. It also supports the development of an inclusive community within the committee, creating an example for further inclusion within the Society as a whole. This approach requires communication at many levels, as well as time for providing feedback. Communication is thus framed as action since it supports the planning and implementation of the committee work, and because communicating with Society members is a key committee action.

Consensus-based decisions about activities related to diversity, equity and inclusion provide multiple pathways for voices to be heard and for solutions to be implemented. The input to our decisions includes rigorous research evidence as well as the experiences and wisdom of committee members. One of our key challenges is the practical translation of this knowledge into accessible and usable information for ASEE members and others in the engineering education community. As we work towards our goal of engagement, one of our actions is to make research and best practices accessible for novices. By including diverse voices in this action, we are more likely to provide information and suggest actions that are broadly useful and have a higher probability of achieving the desired goals during the first implementation.

\section{Key Results}

The ASEE Diversity Committee's work will continue until the engineering community becomes more diverse, equitable, and inclusive. While the Diversity Committee has developed or been involved in many activities, it is important to point out that a diversity climate study was not been performed before the committee's efforts began; therefore, it is difficult to quantify the impact of our efforts. However, the Diversity Committee knows its efforts are affecting the ASEE community through its effects on many individuals. Visibility at the annual conference has increased and personal stories relay that more people feel much more comfortable, welcome, and valued within the community. At this point, 414 ASEE members have attended SafeZone training during ASEE conferences. To date (2017-2018), the Diversity Committee has seen a $122 \%$ increase in division delegates since 2014 (9 to 36) and a 50\% increase in total participation (24 to 36). Labeling the current state and recent activities will enable future assessment.

\section{Future Directions}

The ultimate future of a diversity committee is to be disbanded because the work is complete. Since we are not there yet, there is much that can be done, including expanding the Diversity Committee name from diversity to include equity and inclusion. At the end of the 2018 Annual Conference, the name of the committee will become the ASEE Committee on Diversity, Equity \& Inclusion. The work of the committee has had the broad impact of increasing awareness within the ASEE community. Future work for the committee includes assessing this impact, the foundation for which is included in the 2015-2016 Strategic Plan. The 2017 Diversity Committee is connecting its efforts directly to the 2015-2016 Strategic Plan to increase accountability and 
transparency. In 2018, delegate positions have been opened up to all interested ASEE divisions to encourage inclusion and action across the entire society.

In addition, there has been significant impact on the individuals who have been involved with the Diversity Committee. By creating a space where ASEE members can formally work to raise awareness, build partnerships and develop our community, there has been significant professional development and capacity building of the members. They have been able to develop skills that are useful at their home institutions and they have translated Diversity Committee's roles and experience into leadership positions within ASEE. These pathways are worth studying as the outcomes have resulted in the first African American president of the Society, as well as a cohort of potential future leaders from a wide range of ASEE divisions. Expanding this opportunity by engaging more ASEE members in committee work is one future direction we plan to take.

Moving forward, the committee will continue the work of building partnerships within ASEE and with other societies and alliances in order to improve both engineering education and the field of engineering. One potential way that organizations with low critical mass of underrepresented minorities can address needs, without increasing the work of people who may be asked to be representatives on a larger share of committees, is to create an advocacy committee that supports ways people in the majority can learn and take action. By including the majority in the effort to work on inclusion, equity and expanding diversity, we are more likely to have sustainable change within our Society and our engineering communities.

\section{Acknowledgments}

The authors formally acknowledge the contributions of all past and present ASEE Diversity Committee members and delegates whose hard work and dedication have truly impacted ASEE and the engineering environment. We especially thank Kristen Constant for phrasing suggestions.

\section{References}

[1] C. Herring, "Does diversity pay?: Race, gender, and the business case for diversity," American Sociological Review, vol. 74, no. 2, pp. 208-224, 2009.

[2] N. M. Carter and H. M. Wagner, "The bottom line: Corporate performance and women's representation on boards (2004-2008)," Catalyst, vol. 1, 2011.

[3] S. Devillard, W. Graven, E. Lawson, R. Paradise, and S. Sancier-Sultan, "Women Matter 2012. Making the Breakthrough," McKinsey |\& Company, 2012.

[4] B. L. Yoder, "Engineering by the Numbers," in American Society for Engineering Education, 2017.

[5] Committee on the Underrepresented Groups and the Expansion of the Science and Engineering Workforce and Committee on Science, Engineering, Public Policy and National Research Council, and others, Expanding underrepresented minority participation: America's science and technology talent at the crossroads. National Academies Press, 2010. 
[6] T. Haring-Smith, "Broadening Our Definition of Diversity.," Liberal Education, vol. 98, no. 2, pp. 6-13, 2012.

[7] B. M. Ferdman, "The practice of inclusion in diverse organizations," Diversity at work: The practice of inclusion, pp. 3-54, 2014.

[8] D. M. Hulett, M. Bendick Jr, S. Y. Thomas, and F. Moccio, "Enhancing Women's Inclusion in Firefighting in the USA.," International Journal of Diversity in Organizations, Communities $\& \&$ Nations, vol. 8, no. 2, 2008.

[9] S. Olson and D. G. Riordan, "Engage to Excel: Producing One Million Additional College Graduates with Degrees in Science, Technology, Engineering, and Mathematics. Report to the President.," Executive Office of the President, 2012.

[10] “ASEE Statement on Diversity and Inclusiveness.” [Online]. Available: https://www.asee.org/aboutus/diversity/diversity-statement. [Accessed: 05-Feb-2018].

[11] “Vision, Mission, and Strategic Plan.” [Online]. Available: http://diversity.asee.org/strategy. [Accessed: 05Dec-2017].

[12] ASEE Diversity Committee, “ASEE Diversity Committee Strategy \& Implementation Plan: Objectives, Strategies, Tasks, and Measures," 2016.

[13] “About.” [Online]. Available: http://diversity.asee.org/. [Accessed: 05-Feb-2018].

[14] J. P. Mohsen, "Diversity Committee History and Mission," 2014.

[15] ASEE Engineering Deans Council, "Diversity Initiative Letter," 2017 Available: https://www.asee.org/documents/member-resources/edc/EDC-DiversityInitiativeLetterFinal.pdf.

[16] ASEE Diversity Committee, “ASEE Officers Respond to 'Is All Diversity Good?,” Prism, 2013.

[17] W. Helmer, "Is All Diversity Good?," Prism, 2013.

[18] “The Safe Zone Project.” [Online]. Available: http://thesafezoneproject.com/. [Accessed: 05-Feb-2018].

[19] “ASEE Best Diversity Paper Award.” [Online]. Available: https://diversity.asee.org/bestdiversitypaper. [Accessed: 05-Feb-2018].

[20] R. Green, C. Bilen-Green, and G. Hokanson, “Advocates and Allies.” [Online]. Available: https://www.ndsu.edu/forward/advocates_and_allies/. [Accessed: 04-27-2018].

[21] “Group Decision Making.” [Online]. Available: https://uwaterloo.ca/centre-for-teaching-excellence/teachingresources/teaching-tips/developing-assignments/group-work/group-decision-making. [Accessed: 02-052018].

[22] J. Madden, “A Practical Guide for Consensus-Based Decision Making,” 2017. 